\author{
ANNA CEGIEŁA \\ Uniwersytet Warszawski, Wydział Polonistyki, \\ Instytut Polonistyki Stosowanej, Zakład Edytorstwa i Stylistyki
}

\title{
Etyka słowa w dyskursie publicznym
}

Etyka słowa bada i opisuje relacje działań językowych w stosunku do świata osób i wartości. Działania te mogą być skierowane ku człowiekowi, służyć wartościom. Wspierać je, albo przeciwnie - niszczyć1. Etyczny wymiar działania w języku i za pomocą języka najpełniej ujawnia się w dyskursie publicznym. Dyskurs publiczny jest bowiem obszarem, w którym namacalnie mogą, a przynajmniej powinny móc się realizować wartości uniwersalne, takie jak wolność, równość, godność człowieka i solidarność (zwana wcześniej braterstwem), oficjalnie zadeklarowane i zapisane w ważnych dokumentach międzynarodowych ${ }^{2}$. Do tych ważnych wartości należy również włączyć język, nie tylko w jego konstytutywnej roli tworzenia każdej wspólnoty, lecz także w innych wielokrotnie opisywanych przez językoznawców ${ }^{3}$ funkcjach (przede wszystkim poznawczej, komunikacyjnej, synergicznej).

${ }^{1}$ Etyka słowa jest zatem w gruncie rzeczy etyką komunikacji, zachowań językowych, nie samego języka, bo język jako taki nie może być etyczny lub nieetyczny. Moralne lub niemoralne może być jedynie zachowanie użytkownika języka.

${ }^{2} \mathrm{O}$ tym, jakie wartości powinniśmy chronić w naszych wypowiedziach, pisały J. Puzynina i A. Pajdzińska, zob. Etyka słowa, [w:] O zagrożeniach i bogactwie polszczyzny, Towarzystwo Przyjaciół Polonistyki Wrocławskiej, Wrocław 1996, s. 35-45. Uszczegółowienie zagadnienia znajduje się w: J. Bartmiński, Etyka stowa a potoczny wzorzec komunikacji, [w:] Oblicza polszczyzny, red. nauk. A. Markowski, R. Pawelec, Narodowe Centrum Kultury, Warszawa, s. 32-48.

${ }^{3}$ Pojęcie funkcji poznawczej obecne jest w wielu pracach językoznawczych, np. w Teorii języka K. Bühlera z 1934 roku, wydanie polskie K. Bühler, Teoria języka: o językowej funkcji przedstawiania, TAiWPN Universitas, Kraków 2004 oraz w rozprawie R. Jacobsona, Poetyka w świetle językoznawstwa, Zakład Narodowy im. Ossolińskich, Wrocław 1960; pojęcie synergicznej funkcji języka w: A. Cegieła, Norma wzorcowa i norma użytkowa komunikacji we współczesnej polszczyźnie, [w:] O zagrożeniach i bogactwie polszczyzny, Towarzystwo Przyjaciół Polonistyki Wrocławskiej, Wrocław 1996; funkcję fatyczną wyróżnił B. Malinowski, a R. Jacobson uwzględnił ją w swojej rozprawie. Funkcję komunikacyjną opisywali różni badacze, np. M. Halliday, który uznał ją za jedną z podstawowych funkcji języka (określał ją mianem funkcji interaktywnej). 
Z perspektywy moralnej obserwujemy dziś w dyskursie publicznym (zarówno $\mathrm{w}$ jego głównym nurcie politycznym i medialnym, jak i w pobocznym, nieoficjalnym, np. na forach) kilka negatywnych zjawisk. Są to: brak odpowiedzialności za słowo, znieważanie języka jako wartości oraz jego degradacja jako instrumentu komunikacji, używanie języka jako narzędzia walki z innym człowiekiem oraz narzędzia manipulacji. Zjawiska te obecne są także w ważnych dyskusjach moralnych - starszych z lat dziewięćdziesiątych i nowszych z kilku ostatnich (np. w dyskusji o in vitro $)^{4}$. Charakterystyczne dla polskiego dyskursu publicznego, niezależnie kto go prowadzi, jest to, że ma on charakter konfrontacyjny (czemu sprzyjają media) oraz binarny nie tylko w okresach rywalizacji wyborczej. Te cechy dyskursu są niezwykle trwałe i sprawiają, że, jak pisze M. Czyżewski, ,świadek sporów na scenie politycznej lub w środkach masowego przekazu odnosi nieodparte wrażenie, że porozumienie między przeciwstawnymi stronami jest $\mathrm{z}$ gruntu niemożliwe, a stronom tym nie chodzi o nic więcej, aniżeli o nagłaśnianie własnych racji”. Z badań „Obserwatorium etyki słowa” wynika również, że obraz dwubiegunowości dyskursu powstaje niekiedy w sposób sztuczny, także wtedy, gdy stanowisk w sporze jest więcej lub nie są one spolaryzowane. Dychotomizują go media rywalizujące między sobą o pozycję lidera opinii. Ostra dyskusja publicystów sprawia wtedy wrażenie, że cały spór tak właśnie wygląda. W zasadzie konfrontacyjność i agresja to zjawiska typowe dla kampanii wyborczych. Po ich zakończeniu dyskurs nie jest już tak dynamiczny i nastawiony na konfrontację. Polski dyskurs publiczny odznacza się trwałością tych cech oraz bardzo wyraźną tendencją do odbierania lub ograniczania prawa do udziału w sporze stronie przeciwnej. Podział na tych, którzy zasługują na miejsce w dyskursie i tych, których się z niego wyklucza, wyraźnie też przestaje mieć charakter symboliczny. Nie wyklucza się w Polsce ugrupowań skrajnych (te właściwie zostały już wykluczone). Wyklucza się po prostu przeciwnika. Dyskurs publiczny stał się zespołem strategii komunikacyjnych, wśród których podstawowe miejsce zajmuje retoryka pogardy i wykluczania uzasadniająca stwierdzenie: dyskurs jest nasz i to my mamy nad nim władzę. Tej zasadzie podporządkowane zostało również użycie języka. Wydaje się politykom ${ }^{6}$, że zabiegi tego rodzaju mają funkcję identyfikacji oraz pozycjonowania mediów i wcale nie służą jedynie politykom. Określenie się wobec działania politycznego, interpretacji wydarzeń,

${ }^{4} \mathrm{O}$ degradacji i znieważaniu języka pisze J. Bartmiński w: Etyka słowa a potoczny wzorzec komunikacji, [w:] Oblicza polszczyzny, red. nauk. A. Markowski, R. Pawelec, Narodowe Centrum Kultury, Warszawa, s. 32-48. O języku jako narzędziu walki pisałam w artykułach: Retoryka pogardy w polskim dyskursie publicznym, „Poradnik Językowy” 2012, z. 9, s. 14-25 oraz Czym jest mowa nienawiści?, „Poradnik Językowy” 2014, z. 1, s. 7-17. O instrumentalizacji pojęć pisze P. Kuciński w tekście Etyka wynaleziona, „Poradnik Językowy” 2014, z. 1, s. 18-28. Oba zjawiska były omawiane podczas sesji „Etyka słowa”, która odbyła się na Uniwersytecie Warszawskim w styczniu 2012 r.

${ }^{5}$ Por. M. Czyżewski, S. Kowalski, A. Piotrowski, Rytualny chaos. Studium dyskursu publicznego, Biblioteka Dyskursu Publicznego, Warszawa 2010, s. 59.

${ }^{6}$ Nie ma jeszcze wystarczającej ilości materiału, by uznać, że tak bywa zwykle. 
polityka, ustawy, programów szkolnych, obchodów rocznic itd. jest określeniem własnej pozycji wobec innych mediów oraz wobec opcji politycznych ${ }^{7}$. Władza nad dyskursem oraz określanie własnej pozycji wyraża się np. w definiowaniu, a właściwie redefiniowaniu pojęć. Tolerancja dla mediów liberalnych oznacza akceptowanie różnic między ludźmi, ich odmienności, prawa do przekonań i własnego stylu życia, dla mediów prawicowych jest propagandą homoseksualizmu oraz ideologii gender, czyli tolerowaniem zła. Pojęcie narodu rozumiane jest również pragmatycznie: może nazywać elektorat prawicy, zastępować pojęcie społeczeństwa, odnosić się do wierzących lub określać wspólnotę etniczną. Definicje takich pojęć są sygnałami rozpoznawczymi przynależności dyskursu lub, mówiąc inaczej, zawłaszczaniem języka.

Filozofowie, językoznawcy, retorycy mówiący o możliwościach porozumienia między uczestnikami sporów publicznych są uznawani za idealistów albo wręcz za nieszkodliwych, ale i nieużytecznych epigonów minionej epoki, ich teorie traktuje się nieco za dosłownie ${ }^{8}$. Aktorzy polskiej sceny politycznej i mediów najwyraźniej przystają na to, że każda dyskusja jest formą walki, a prawda i szacunek dla drugiego to zbędny luksus, na który nie stać polskich mediów.

Nieetyczność językowa polskiego dyskursu przejawia się zarówno w postawach wobec sytuacji komunikacyjnej, przedmiotu dyskusji, jak i wobec innych uczestników sporu.

Zacznijmy od postaw uczestników dyskursu wobec sytuacji komunikacyjnej. Dyskusje o aborcji, in vitro i związkach partnerskich pokazały, po pierwsze, że podjęto dyskusję niespełniającą warunków racjonalności, pozorną, bez intencji negocjowania warunków komunikacyjnych, po drugie, z góry zakładano pokonanie przeciwnika, a nie dyskutowanie $\mathrm{z}$ nim, załatwienie partykularnych interesów, nie zaś spór o dobro sprawy, po trzecie, przyjęto, że przeciwną stronę można wyeliminować albo chociaż zdyskredytować, ośmieszyć i zmarginalizować. Nie ma obowiązku wysłuchania jej racji. Do dyskusji nad ustawami uczestnicy sporu podeszli z przekonaniami nieopartymi na wiedzy racjonalnej albo, co gorzej, $\mathrm{z}$ uprzedzeniami do drugiej strony sporu'. W dyskusji nad ustawą o in vitro nie

7 Wyraźnie widać to w tekstach tygodnika „W Sieci”, który przyjmuje pozycję bardziej na prawo niż „Do Rzeczy” i „Gazeta Polska”.

${ }^{8}$ Por. krytykę koncepcji H. P. Grice’a oraz J. Habermasa, którym zarzuca się idealizm. Grice'a krytykował np. S. C. Levinson (Pragmatics, Cambridge University Press 1983), a Habermasa E. Tugendhat (Wyktady o etyce, Oficyna Naukowa, Warszawa 2004). Krytyka teorii Grice'a znajduje się w niepublikowanym tekście B. Walczaka, który autor przedstawił na Forum Kultury Słowa w Rzeszowie.

${ }^{9}$ Spór o aborcję szczegółowo opisany został w pracy Cudze problemy. O ważności tego, co nieważne. Analiza dyskursu publicznego w Polsce, M. Czyżewski, K. Dunin, A. Piotrowski (red.), Ośrodek Badań Społecznych, Warszawa 1991; spór o metodę in vitro w artykule A. Cegieły, Dyskusja o metodzie in vitro jako spór źle prowadzony, „Poradnik Językowy” 2011, z.10, s. 10-31 oraz w rozdziale Metoda in vitro - grzech czy odblask łaski bożej, [w:] Moralność w perspektywie stownika i wypowiedzi. Studium z zakresu leksykologii i pragmatyki językowej, Wydawnictwo Wydziału 
próbowano rozpoznać intencji uczestników sporu, przypisywano sobie nawzajem jedynie złe intencje. Media zaogniły ten spór, eksponując niefortunne i nie najważniejsze wypowiedzi. Zwolennikom metody in vitro zarzucano chęć wprowadzania do medycyny zasad eugeniki, wspieranie lobby lekarskiego, samą metodę porównano z aborcją i uznano za najcięższy grzech człowieka przeciw Stwórcy. Kościołowi z kolei stawiano zarzut hipokryzji, posądzano go o chęć sprawowania władzy nad wszystkim ludźmi, także niewierzącymi i porównywano z talibami.

Stosunek uczestników dyskursu do przedmiotu sporu powinien wynikać z rozeznania, możliwości wniesienia oraz uzasadnienia istotnych racji. Dyskutujący nie mieli jednak właściwego rozeznania w kwestiach, o których dyskutowali, chociaż mogli skorzystać z ekspertyz. W dyskusji nad ustawą antyaborcyjną, kiedy już ekspertyzy zostały przygotowane, strona zwana ,pro life” zanegowała kompetencje i bezstronność ekspertów drugiej strony i za wszelką cenę starała się unieważnić udokumentowane przypadki chorób uniemożliwiających urodzenie dziecka (bo groziłoby to kobiecie utratą życia), czyli zaprzeczyć faktom po to, by doprowadzić do całkowitego zakazu aborcji, także ze wskazań medycznych. Selekcja i negacja rzeczowych argumentów drugiej strony spowodowała przeniesienie całej dyskusji na poziom ideologiczny. Przedmiotem sporu miała być ochrona dziecka poczętego, stała się nim wygrana ,pro life” za wszelką cenę, także za cenę życia matki, a także rola kobiety w społeczeństwie (rolę tę określono jako rolę strażaka idącego do pożaru i gotowego poświęcić życie).

W sporze o in vitro posłowie byli zobligowani do prawnego skonkretyzowania na poziomie ustawodawczym zasad Konwencji Bioetycznej Rady Europy (konwencję podpisał rząd Jerzego Buzka w 1999 r.). Oznacza to, że powinni określić zasady ochrony embrionów ludzkich i prawnie wyrazić prymat interesu i dobra jednostki nad wyłącznym interesem społeczeństwa i nauki. Do roku 2006 posłowie nie przygotowali ustawy, natomiast uczestnicy sporu - głównie przedstawiciele partii, Kościoła i dziennikarze sprowadzili go do postaci: postęp kontra Kościól, albo eugenika kontra ofiara. Do dziś nie zlecono analizy standardów postępowania w klinikach zajmujących się zapłodnieniem pozaustrojowym, co powinno być podstawą dyskusji o ustawie bioetycznej. Uczestnicy sporu dyskutowali o czymś, czego dobrze nie znali. Politycy próbowali uzyskać korzyści partyjne $\mathrm{z}$ licytowania się, kto przyzna więcej praw bezpłodnym parom lub parom homoseksualnym i, choć niczego nie ustalono, obiecywano finansowanie procedury z budżetu NFZ. O zainteresowaniu posłów problemem in vitro świadczy też fakt, że na wysłuchanie obywatelskie w sejmie oprócz Marka Balickiego nie przyszedł żaden z nich.

Polonistyki UW, Warszawa 2011, s. 120-145. W tekstach przeciwników metody in vitro mówi się o lobby lekarskim zainteresowanym metodą, a nie wspomina o cierpieniu bezpłodnych par, w tekstach zwolenników metody za winnego nieuchwalenia ustawy uznaje się Kościół katolicki, por. J. Hartman (GW, 25.02.2013). 
Biorący udział w sporze księża posłużyli się niesprawdzonymi informacjami dotyczącymi rozpoznawalnych wad genetycznych u dzieci z in vitro, dostarczonymi przez uczestników sympozjum w Białymstoku (w Polsce zbadano tylko 16 dzieci urodzonych dzięki metodzie in vitro, co nie daje podstaw do jakikolwiek uogólnień).

Z kolei przedstawiciele mediów opowiadających się za wprowadzeniem in vitro nawet nie spróbowali się dowiedzieć, na czym opierają się argumenty przedstawicieli Kościoła, skąd księża protestujący przeciw powoływaniu dodatkowych zarodków czerpią swoją wiedzę o ich wykorzystywaniu w eksperymentach genetycznych ${ }^{10}$. Przyjęcie przez dziennikarzy postawy ignoranta, ale z wyrazistymi przekonaniami, doprowadziło do skrajnego zantagonizowania stron sporu i jego obserwatorów. Nieprofesjonalnym i nierzetelnym opisem problemu dziennikarze zdezorientowali ludzi zainteresowanych metodą in vitro i wywołali niechęć do Kościoła i katolików. Strona kościelna z kolei manipulowała obrazem metody in vitro, a tym samym przedmiotem sporu i kładła nacisk na sprzeczność metody z prawem naturalnym, co dla ludzi niewierzących nie mogło stanowić istotnego argumentu. Z jednej strony dziennikarze nierozumiejący, czym jest ekskomunika, pisali, że Kościół straszy nią bezpłodnych rodziców i sprowadzali postawę Kościoła do formuły „,prawo naturalne zabrania in vitro”. Nie pytali ani o znaczenie terminu ,prawo naturalne”, ani o jego konkretne odniesienie. $Z$ drugiej strony prasa katolicka pisała o tym, że aby urodzić dziecko z in vitro, trzeba poświęcić nawet kilkadziesiąt zarodków. Tymczasem standardy w polskich klinikach są bardzo wysokie, a troska o zarodki wyższa niż w wielu innych krajach europejskich ${ }^{11}$.

W postawach uczestników przywołanych tu sporów wobec warunków i przedmiotu dyskusji ujawniły się więc różne nieetyczne zachowania.

Po pierwsze, obraz przedmiotu sporu kształtowano w sposób nieprawdziwy, ale korzystny dla jednej ze stron i zgodny z jej przekonaniami. Na przykład, dla jednej strony sporu in vitro mogło być młodszą siostrą eugeniki, technologią i biznesem lobby lekarskiego, dla drugiej - szansą, metodą prowadzącą do urodzenia własnego dziecka, wręcz odblaskiem łaski Bożej.

Po drugie, eliminowano (selekcjonowano) informacje o przedmiocie sporu korzystne z racjonalnego punktu widzenia dla drugiej strony. Na przykład marginalizowano dylemat moralny związany z wyborem między śmiercią matki a usunięciem ciąży grożącej jej życiu.

Po trzecie, ideologizowano spory, hamując rzeczową dyskusję. Argumentom takim, jak cierpienie, zagrożenie życia, naturalna potrzeba urodzenia własnego dziecka, przeciwstawiano zasady religijne.

${ }^{10}$ Eksperymenty takie są rzeczywiście przeprowadzane np. w Wielkiej Brytanii i w Niemczech. Odpowiedni zapis ustawy może je jednak zablokować w Polsce.

${ }^{11}$ Informację taką uzyskałam w klinice ginekologicznej, w której pytałam, na czym metoda polega, jak się ją stosuje oraz właśnie o standardy przeprowadzania zabiegów. 
„Niepłodność to trauma na całe życie” - mówi jedna z dyskutujących o in vitro kobiet. Inna dodaje: „Niepłodność to choroba. Nie umiera się od niej. Ale umiera się od środka” (Chcę urodzić dziecko, to moje prawo, „Dziennik”, 29.12.2008). Biskup Pieronek: „Pary korzystające z in vitro mówią: mamy prawo do dziecka. Pytam się: jakie prawo? Skąd to prawo wynika? [...] Każde dziecko jest darem Bożym, niezależnie od tego, jak przyszło na świat i co towarzyszyło jego poczęciu. Ale ta prawda nie daje podstaw do twierdzenia, że mamy prawo manipulować życiem i zastępować naturalny proces poczęcia. [...] Nie wolno myśleć, że skoro Bóg nie obdarzył mnie dzieckiem, to mam prawo starać się o nie wbrew Jego woli” (Wiadomości, onet.pl, 16.01.2009).

Po czwarte, dychotomizowano spór, sprowadzając wszystkie problemy do dwóch stanowisk, zwykle związanych jeszcze z dwiema orientacjami politycznymi (prawica i lewica), co nie odpowiada ani podziałowi stanowisk w sporze, ani sytuacji na scenie politycznej. Obserwator sporu odnosi wrażenie, że można być za in vitro albo przeciw niemu, a nie widzi kwestii znacznie bardziej skomplikowanych, które ustawa powinna regulować (dotyczących np. ochrony zarodków, liczby zabiegów, które może mieć jedna kobieta itp.). Media tak kształtujące obraz dyskursu naruszają natomiast zasady etyki dziennikarskiej i uczestniczą w rozgrywkach politycznych. W tym wypadku bowiem dychotomizację sporu wzmacnia nie tylko opowiedzenie się dziennikarzy za wprowadzeniem metody, lecz także przedstawianie przez nich członków partii i polityków jako tych wrażliwych na ludzkie cierpienie zwolenników ustawy zezwalającej na zabiegi oraz tych ograniczanych przez Kościół jej przeciwników. Biorąc pod uwagę to, że dyskusja o in vitro jest jednym z ważniejszych sporów moralnych epoki, media powinny ją pokazywać rzetelnie, nie zajmując żadnego stanowiska. Opowiadanie się po którejkolwiek ze stron nie pomaga $\mathrm{w}$ rozstrzygnięciu sporu, służy raczej walce $\mathrm{z}$ jakimś przeciwnikiem. Tymczasem czytamy: „In vitro. Talibów wojna z dziećmi” (okładka „Newsweeka” z lipca 2012), „Kościół zatracił miarę” (tytuł w GW,15.04.2013), ,mamy coś w rodzaju stanu wyjątkowego” (GW, 15.04.2013), „arcybiskup Hoser zagroził posłom popierającym in vitro ekskomuniką"12 (GW, 09.04.2013), „Dobrze by więc było, gdyby zamiast analizować niefrasobliwość rzekomych «techników», duchowni przyjrzeli się własnej" (GW, 02.01.2012). Takie wypowiedzi niezależnie od ich wartości racjonalnej odbierane są przede wszystkim jako atak na Kościól, a także opowiedzenie się po stronie lewicy.

Postawy uczestników dyskursu wobec partnerów również są uwarunkowane w znacznej mierze przez przekonania, emocje oraz orientację ideologiczną lub polityczną, a w mniejszym stopniu przez wiedzę i inne czynniki racjonalne. Mówiąc inaczej, w sporach publicznych częściej daje się upust emocjom, reaguje na pozycję i przynależność polityczną lub religijną oponenta, a nie na sens jego wy-

12 Biskup Hoser nie mówił o ekskomunice, lecz o postawieniu się poza wspólnotą Kościoła, a to co innego. 
powiedzi, dyskutuje się, aby z nim wygrać, bo to daje siłę, pozycję, władzę oraz oglądalność. Przeciwnik w sporze przestaje być rozmówcą, staje się wrogiem, którego należy zniszczyć. Obserwator również nastawiony jest na to, że właśnie niszczenie przeciwnika zobaczy. Zjawisko to widoczne jest już w tytułach tekstów medialnych, np. „Prof. Pawłowicz masakruje Kuźniara” (Fronda, 25.05. 2013).

Większość z obserwowanych przeze mnie sporów ma charakter retoryczny, a nie merytoryczny, konfrontacyjny, a nie racjonalny. To, co w dyskursie ostatnich dwudziestu lat wydaje się charakterystyczne, to właśnie tendencja do konfrontacji, do szukania winnego, odpowiedzialnego za niewłaściwy stan rzeczy, zamiast poszukiwania rozwiązań, oraz przekonanie, że spór toczy się po to, żeby ktoś go wygrał, a wygrany może być tylko jeden. Oto charakterystyczny przykład jednego z takich właśnie głosów w sporze: „To, że in vitro jest w Polsce całkowicie dozwolone i nieuregulowane, co prowadzi do różnych nieszczęść, jest zawinione przez Kościół, który odmawia państwu prawa do uregulowania in vitro, oczekując nierealistycznie całkowitego zakazu" (J. Hartmann, GW, 25.02.2013).

Media przedstawiające dyskurs wspierają te negatywne tendencje, eksponując te zachowania uczestników sporu, które decydują o jego dychotomicznym i konfrontacyjnym charakterze, nie hamują zachowań określanych jako tzw. techniki forsowania, przeciwnie, same je wykorzystują.

Do programów o ważnych problemach moralnych i politycznych zaprasza się ludzi o skrajnych poglądach, mających krańcowo różne postawy i przedstawia się ich jako reprezentantów dwóch stron sporu. Czy są oni rzeczywiście reprezentantami stron, to kwestia bez znaczenia. Ważne staje się to, by mieli różne zdania na jeden temat, by dyskusja stała się wojną, by antagoniści nawzajem się atakowali. Wtedy zwiększa się oglądalność i przybywa tematów do kolejnych audycji. Takie postępowanie zwiększa stopien dychotomizacji sporu, odbiera debacie walor racjonalności, gdyż uczestnicy sporu medialnego, zamiast posługiwać się argumentami, prezentują swoje przekonania i opinie, co antagonizuje również uczestników debaty właściwej. A język, który wspólnotę konstytuuje, staje się narzędziem jej destrukcji. Wyraźnie widać to w dyskursie o in vitro, w dyskursie smoleńskim, dyskursie narodowym i innych. Ludzie, którzy dyskusję podjęli, stopniowo zmieniają się z dyskutantów we wrogów.

Rejestr nieetycznych zachowań językowych jest długi. Obejmuje stereotypizację, stygmatyzowanie, uwłaczanie, dyskredytację, często połączoną z hiperbolizacją, degradację, marginalizację, pogardę, wykluczanie, arbitralną zmianę znaczeń, używanie zgubnej koniunkcji, budowanie fałszywych alternatyw ${ }^{13}$. Zabiegi te stosują wszyscy uczestnicy dyskursów. Zmienne są tylko proporcje doboru środków z tego arsenału i stylistyczny charakter zabiegów językowych.

To, co wydaje się najgroźniejsze, to powtarzalność schematu obecnego wcześniej w systemach totalitarnych i znanego z publikacji Jeana Hatzfelda o wojnie

13 Por. A. Cegieła, Retoryka pogardy w polskim dyskursie publicznym, „Poradnik Językowy” 2012, z. 9, s. 14-25: taż, Czym jest mowa nienawiści?, „Poradnik Językowy” 2014, z. 1, s. 7-17. 
Hutu i Tutsi, schematu strategii nienawiści, nazwanego przez Giorgio Agambema „włączającym wykluczaniem”. Stosuje się je wobec wybranych osobników i polega ono na tym, że odbiera się im prawo uczestnictwa w dyskursie, w gruncie rzeczy odbierając także prawa ludzkie. Wyłączonych można wyśmiewać, obrażać, poniżać oraz izolować. W ten sposób narusza się ważne wartości: równość i wolność (bo podważa się prawo inkluzji w komunikacji) oraz godność (bo okazuje się pogardę i nienawiść).

Strategia nienawiści ma kilka etapów.

Pierwszy to kształtowanie czyjegoś negatywnego obrazu (czyli zabiegi dyskredytacji i stygmatyzowania). Osoba lub grupa tak opisywana ma wyłącznie cechy negatywne, budzące odrazę, pogardę. Nie jest ważne, czy cała grupa ma takie negatywne i dyskredytujące cechy. Ważne, by został ukształtowany pewien stereotyp grupy i przekonanie, że odznacza się nimi każdy z jej członków. Tak więc najpierw odbywa się etykietowanie, a potem stygmatyzacja.

I oto „historyk z IPN-u” to gorszy, marny i tendencyjny historyk, będący pod wpływem PiS-u i szukający kwitów na Wałęsę, „dziennikarz prawicowy” to zwolennik sekty, „bezrobotny” to osoba roszczeniowa, niezaradna, „matka kilkorga dzieci" to kura domowa zdominowana przez męża o osobowości macho, przeciwnik małżeństw homoseksualnych to nie sceptyk, lecz ,przedstawiciel Ciemnogrodu”, przynoszący wstyd Polsce. „Liberał” to przeciwnik normalnej rodziny, negujący zdrowe zasady moralne. Jeśli cała grupa nie posiada wszystkich negatywnych cech, to i tak można jej to przypisać:

Nietrudno przewidzieć, jak wyglądałaby dyskusja polityczna na ten temat [antykoncepcji]. Rozgrzana do czerwoności prawica rzucająca oskarżenia o eugeniczne ciągoty, o zmuszanie katolików do grzechu, uderzanie w katolicką rodzinę i prawo naturalne, mantry znane od lat. (Polityka, 08.05.2013, s. 27)

Po stworzeniu pewnego stereotypu (odebraniu wielowymiarowości grupie) można ją degradować, czyli uzupełniać obraz o kolejne negatywne cechy. Można ukazać jej obraz jako grupy niebezpiecznej, zagrażającej prawom innych. „Zwolennik sekty smoleńskiej” stanie się na tym etapie „fundamentalistą” albo osobą „bezprawnie wyłudzającą odszkodowania od państwa”. Oto kilka wymownych przykładów:

Krzepnie nam sekta bez wiary w zwycięstwo, ale z wiarą w trwanie. Złorzeczenia i paranoiczne podejrzenia powodują, że coraz głębiej wchodzimy w szczegóły, jak poćwiartowane były ciała, potem jak pięknie niektóre zszyto, a innych nie udało się nic a nic [...]. Paranoicy wszystkich krajów łączcie się! (Newsweek, 06.11.2010)

Polskiej zimnej wojny nie da się wytłumaczyć bez psychologii. [...] Kluczem jest osobowość prezesa. Zaprzyjaźniony psychiatra postawił diagnozę, ale zakazał jej publikowania. (Newsweek, 25.09.2010)

Odpowiednio zohydzony osobnik lub grupa nie mają już praw. Nie stosuje się już wobec nich reguł obowiązujących wobec innych członków społeczeństwa 
i nie wywołuje to protestów. Można nazywać ich „zwierzętami”, „chorymi psychicznie”, „fundamentalistami katolickimi” (licząc na skojarzenia z fundamentalistami islamskimi), „hienami cmentarnymi”, „małpą z brzytwą”, naruszać tabu kulturowe, czyli np. wyśmiewać ich poczucie straty bliskich, nawet opluwać i bić. Deklaruje się, że „dorżniemy watahę, albo że raz sierpem, raz młotem czerwoną hołotę".

Zawieszenie normalnych praw ilustrują też słowa odnoszące się do głowy państwa:

Lech Kaczyński nie wie, kto stał za tym atakiem, ale cieszy się, że żyje, niestety jest odosobniony w tym uczuciu. (J. Wojewódzki, Poranny WF, 19.03.2009)

Mały, głupi, niedorozwinięty człowiek, zwany prezydentem Polski, Lech Kaczyński. (M. Figurski, Poranny WF, 19.03.2009)

Już sam fakt, że nie ma brata bliźniaka, staje się wielką zaletą. (Newsweek, 31.04.2010)

Kiedy znamy kogoś, kto ma pisowskie poglądy, mówimy o takim osobniku, jakby był chory na wstydliwą chorobę. (Newsweek, 08.01.2011)

Warto zauważyć, że podstawą takich działań jest swoiste przekonanie grupy perswazyjnej o istnieniu jakiegoś wyobrażonego ładu opartego na słusznych zasadach. Ani ten ład, ani budujące go zasady nie są konkretne. Ważne, że są one tworzone przez ludzi, a niszczone przez innych - nieludzi, antyludzi groźnych, chorych na paranoję, mających kompleksy przeszłości, niemoralnych. $\mathrm{W}$ imię pozornego ładu można tych obcych, nieludzi słownie obrażać, stygmatyzować, marginalizować. Taki rodzaj myślenia stanowi niebezpieczne usprawiedliwienie, przyzwolenie na dalsze dehumanizujące działania słowne i, jak pokazuje historia, fizyczne. Te działania to najpierw zwykle postulaty wykluczenia lub co najmniej ograniczenia praw. Oczywiście, nie wszystkie tego rodzaju zachowania słowne mają taki systematyczny charakter. Systematycznie buduje się obraz Kościoła, który zajmuje się odzyskiwaniem majątku, robieniem mętnych interesów, hamowaniem postępu w medycynie, kontrolowaniem życia seksualnego katolików oraz pedofilią. Taki kościół należy z dyskursu wykluczyć i to zostaje sformułowane explicite:

A po co w ogóle pytać biskupów o zdanie? Kościół ma prawo swoje zasady religijne i moralne egzekwować na terenie, który jest mu właściwy - np. w konfesjonale. Tam można sprawować władzę nad sumieniem jednostki. Mam wrażenie, że wprawdzie rząd formalnie nie pytał o zdanie biskupów, ale zachowuje się, jakby pytał. Podobnie media - jak gdyby pytały Kościół, na co pozwoli, a na co nie pozwoli. A Kościół to wykorzystuje, by zaprzęgać państwo do obrony swoich wątpliwych wartości. Chodzi przede wszystkim o władzę nad ludźmi. Biskupi doskonale wiedzą, ile mogą osiągnąć swoimi religijnymi środkami. Sięgają więc po władzę poza Kościołem, wywierają presję na rząd i domagają się ustaw takich lub innych, które by Kościołowi pomagały utwierdzać zasięg wpływów religii. [...] Powstaje też pytanie, na czym kler opiera swoją pewność siebie, bo ani moralnych, ani intelektualnych podstaw do tego nie widać. (B. Łagowski, „Gazeta Wyborcza”, 28.12.2007) 
Wykluczający charakter ma też wypowiedź Jacka Żakowskiego, będąca elementem szerszej oceny pracy ministra Gowina: „Wydaje mi się, że jest to jeszcze gorszy chwast polityczny niż Jan Rokita czy Zyta Gilowska, którzy symbolizują najgorszy okres Platformy" (GW, 24.08.2013). Zabawna, zdaniem dziennikarzy, propozycja uczniów wobec ministra edukacji: „Giertych do wora, wór do jeziora”, nie wpisywała się już w szersze i systematyczne działania językowe, chociaż jej tolerowanie było świadectwem przyzwolenia na takie działania.

Czy na pewno mamy prawo do takich wypowiedzi w przestrzeni publicznej?

Wypowiedzi wykluczające to jedno z najcięższych rodzajów przestępstw wobec partnerów/wrogów w dyskursie. Warto jednak zauważyć, że szkodliwe są i te mniej groźne: nazwanie homoseksualistów bezproduktywnymi społecznie (a więc zbędnymi ze społecznego punktu widzenia), przedstawianie Ukrainek jako osób gorszych, niezasługujących na szacunek, nad którymi Polak ma władzę, kibiców jako kiboli, uczestników Marszu Niepodległości jako faszystów szerzących za pomocą transparentu „Bóg, Honor i Ojczyzna” język nienawiści. Wyraźnie widać tu nawiązanie do niechlubnej tradycji nowomowy - odświeżania sprawdzonych mechanizmów arbitralnego nadawania znaczenia wyrazom i pragmatycznego używania określeń wartościujących: „faszysta” to "uczestnik Marszu Niepodległości', bojówkarz z Niemiec napadający grupę rekonstrukcyjną to „członek Antify, który uchronił pokojową manifestację od masakry".

Stosunkowo nowy (około dwudziestoletni) wydaje się natomiast mechanizm zgubnej koniunkcji (zaraźliwego sąsiedztwa) - „nie zabijam, nie kradnę, nie wierzę”; ,,aborcja, eutanazja, zawodowa praca kobiet”; ,bezrobocie, alkoholizm, narkomania, małodzietność”; „pedofilia, prostytucja, pornografia i antykoncepcja”. Nie pojmuję, dlaczego ten pierwszy szereg został przez Magdalenę Środę oceniony publicznie jako dowcipny i niewinny. Łączy przecież manifestacyjnie nazwy dwóch przestępstw z wiarą, sugerując, że wiara w Boga też jest przestępstwem.

Zachowania nieetyczne, także nieetyczne językowo, widzi się przede wszystkim przez pryzmat ich skutków społecznych. Na zakończenie wskażę więc kilka takich szczególnie niepożądanych rezultatów nieetycznego użycia słowa w dyskursie.

Pierwszym negatywnym efektem braku etyczności w komunikacji jest utrwalenie fałszywego i uproszczonego obrazu problemu i uczestników sporu wyobrażonego w fałszywej alternatywie. Na przykład: europejskość albo patriotyzm; homofobia albo nowoczesna ustawa partnerska; zaścianek, Ciemnogród albo in vitro; ciemna prawica albo nowoczesna lewica; albo aborcja i eutanazja albo klechistan/dyktatura kleru; albo Żyd, albo patriota, albo konserwatysta, albo światły obywatel, czyli albo my albo wy. Tak skonstruowana sztuczna alternatywa oznacza faktycznie bezalternatywność lub nakaz określonego przez innych wyboru. $Z$ etycznego punktu widzenia jest zatem mającym charakter manipulacyjny ograniczaniem autonomiczności (suwerenności) jednostki. 
Drugim skutkiem jest utrwalanie się uproszczonego, stereotypowego myślenia o przeciwniku w sporze, sugerowanego głównie przez media, a będącego wynikiem wiary w ukrytą teorię osobowości: jeśli ktoś jest liberałem, to jest zwolennikiem aborcji, eutanazji, związków partnerskich; jeśli jest katolikiem (katolem), to na pewno jest ciemniakiem, przeciwnikiem antykoncepcji; jeśli jest prawicowcem albo pisowcem, to jest fundamentalistą katolickim; jeśli ktoś jest liberałem, to nie może być patriotą; jeśli jest pisowcem, to może świętować tylko przegrane powstania i inne smutne rocznice.

Te dwa zjawiska utrwalają dychotomię polskiego dyskursu publicznego. Język zamiast pełnić funkcję synergiczną, pomagać we wspólnym działaniu, sprzyja budowaniu czarno-białej rzeczywistości, utrwala stereotypy i sprzyja rodzeniu się uprzedzeń.

Za trzeci negatywny rezultat nieetycznego traktowania możliwości dialogu uznałabym wiarę $\mathrm{w}$ jeden obowiązujący wzorzec myślenia sugerowany przez media i oparty na ideologii poprawności politycznej lub sile grupy perswazyjnej, uznający tylko jedną rację - kwintesencją takiego myślenia są dwie wypowiedzi Kolendy-Zaleskiej: „Żadne fakty nie mogą zmienić rozstrzygnięć komisji Millera” i Tekielego: „Bioterapia, różdżkarstwo i joga to pakt z szatanem”.

Przekonanie, że mamy prawo naruszać czyjąś godność, równość, że przysługuje nam prawo ograniczania czyjejś wolności w imię jakiegoś wyimaginowanego ładu i dlatego, że jacyś „oni” na to zasłużyli, to kolejny, czwarty rezultat nieodpowiedzialnego traktowania sytuacji sporu. Przekonanie takie to w gruncie rzeczy przeświadczenie o tym, że jakiejś grupie przysługuje władza nad mową i nad inną grupą ludzi. To również krok w stronę banalizacji nieetycznych wypowiedzi publicznych - tak często mówi się przeciwko człowiekowi, że nie warto już tego piętnować, można nie zwracać na to zjawisko uwagi. Taki rodzaj myślenia to przejaw moralności kolektywnie zredukowanej, rezygnującej z refleksji nad wartościami i odpowiedzialności za nie.

\section{Bibliografia}

Agambem G. [2008], Homo sacer. Suwerenna władza i nagie życie, Prószyński i S-ka, Warszawa. Bartmiński J. [2012], Etyka słowa a potoczny wzorzec komunikacji, [w:] Oblicza polszczyzny, red. nauk. A. Markowski, R. Pawelec, Narodowe Centrum Kultury, Warszawa, s. 32-48.

Bühler K. [2004], Teoria języka: o językowej funkcji przedstawiania, TAiWPN Universitas, Kraków. Cegieła A. [1996], Norma wzorcowa i norma użytkowa komunikacji we wspótczesnej polszczyźnie, [w:] O zagrożeniach i bogactwie polszczyzny, J. Miodek (red.), Wrocław.

Cegieła A. [ 2011], Metoda in vitro - grzech czy odblask laski Bożej, [w:] Moralność w perspektywie słownika i wypowiedzi. Studium z zakresu leksykologii i pragmatyki językowej, Wydawnictwo Wydziału Polonistyki UW, Warszawa, s. 120-145.

Cegieła A. [2011], Dyskusja o metodzie in vitro jako spór niewłaściwie prowadzony, „Poradnik Językowy", z. 10, s. 10-31. 
Cegieła A. [2012], Retoryka pogardy w polskim dyskursie publicznym, „Poradnik Językowy”, z. 9, s. $14-25$.

Cegieła A. [2014], Czym jest mowa nienawiści?, „Poradnik Językowy”, z. 1, s. 7-17.

Czyżewski M., Dunin K., Piotrowski A. (red.) [1991], Cudze problemy. O ważności tego, co nieważne. Analiza dyskursu publicznego w Polsce, Ośrodek Badań Społecznych, Warszawa.

Czyżewski M., Kowalski S., Piotrowski A. (red.) [2010], Rytualny chaos. Studium dyskursu publicznego, Biblioteka Dyskursu Publicznego, Warszawa, s. 59.

Głowiński M. [2009], Nowomowa i ciagi dalsze. Szkice dawne i nowe, TAiWPN Universitas, Kraków.

Hatzfeld J. [2009], Strategia antylop, Wydawnictwo Czarne, Wołowiec.

Hatzfeld J. [ 2011], Nagość życia. Opowieści z bagien Rwandy, Wydawnictwo Czarne, Wołowiec.

Hatzfeld J. [2012], Sezon maczet, Wydawnictwo Czarne, Wołowiec.

Jacobson R. [1960], Poetyka w świetle językoznawstwa, Zakład Narodowy im. Ossolińskich, Wrocław.

Język IV Rzeczypospolitej [2010], M. Czerwiński, P. Nowak, R. Przybylska (red.), Wydawnictwo UMCS, Lublin.

M. Karwat [2006], O złośliwej dyskredytacji. Manipulowanie wizerunkiem przeciwnika, PWN, Warszawa.

Kmiecik S. [2013], Przemyst pogardy, Prohibita, Warszawa.

Kowalski S., Tulli M. [2003], Zamiast procesu. Raport o mowie nienawiści, Wydawnictwo WAB, Warszawa.

Kuciński P. [2014], Etyka wynaleziona, „Poradnik Językowy”, z. 1, s. 18-28.

Levinson S.C. [1985], Pragmatics, Cambridge University Press, Cambridge.

Pajdzińska A., Puzynina J. [1996], Etyka słowa, [w:] O zagrożeniach i bogactwie polszczyzny, Towarzystwo Przyjaciół Polonistyki Wrocławskiej, Wrocław, s. 35-45.

Tugendhat E. [2004], Wyktady o etyce, Oficyna Naukowa, Warszawa. 